\title{
The Factors Affecting Kyrgyzstan's Bilateral Trade: A Gravity-model Approach
}

\author{
Piratdin Allayarov ${ }^{1}$, Bahtiyar Mehmed ${ }^{2}$, Sazzadul Arefin ${ }^{3}$, Norbek Nurmatov ${ }^{4}$
}

Received : March 29, 2018 Revised: April 7, 2018 Accepted: July 30, 2018

\begin{abstract}
The study investigates the factors that affect Kyrgyzstan's bilateral trade flows with its main trading partners and attempts to predict trade potential for Kyrgyzstan. Using panel data, the gravity model is applied to estimate Kyrgyzstan's trade from 2000 to 2016 for its 35 main trading partners. The coefficients derived from the gravity-model estimation are then used to predict trade potential for Kyrgyzstan. Results proved to be successful and explained 63\% of the fluctuations in Kyrgyzstan's trade. According to the results, Kyrgyzstan's and its partners' GDP have a positive effect on trade, while distance and partners' population prove to have a negative effect. Predicted trade potential reveals that neighboring countries (China, Kazakhstan, Uzbekistan, and Tajikistan) and Russia still have a significant trade potential. Kyrgyzstan, being a less developed economy, even by Central Asia standards, can only achieve its goals of reducing poverty and becoming more developed by increasing its overall trade with the rest of the world. Therefore, it is essential to study the main determinants of Kyrgyzstan's bilateral trade. In this way, we can help policy makers formulate policies to expand Kyrgyzstan's trade. This study is the first attempt to apply to the gravity model to Kyrgyzstan in an attempt to predict trade potential.
\end{abstract}

Keywords: Bilateral Trade, Gravity Model, Economic Policy, Kyrgyzstan.

JEL Classification Code: C33, F14, F17.

\section{Introduction}

Foreign trade plays a significant role in international economic integration. It helps to overcome the limited resources and narrowness of internal regional and national markets, to increase the possibility of organizing mass production, and the degree of equipment loading. It also increases the efficiency of maintaining new equipment and technologies, improves the economic growth rate, and

1 First Author and Corresponding Author. PhD Student, School of Economics and Trade, Hunan University, Changsha, China [Postal Address: 2 Lushan S Rd, Yuelu-Qu, Changsha, Hunan Province, China, 410006] E-mail: pikon2003@mail.ru

2 Associate Professor, Neusoft Institute Guangdong, China. Email: b_mehmed@yahoo.com

3 PhD Student, School of Economics and Trade, Hunan University, Changsha, China. E-mail: showmikju@gmail.com

4 PhD Student, School of Economics and Trade, Hunan University, Changsha, China. E-mail: norbek8@mail.ru promotes the more rational use of natural resources and labor. At the end of the twentieth century, like many other post-Soviet republics, the Kyrgyz Republic started the transition to market relations. There has been a fundamental shift in foreign economic policy from relative closure to an open economy and integration into the system of world economic relations, including the liberalization of all forms of foreign economic relations. Implementing a well-defined and balanced trade and economic policy will also help to solve internal economic problems, increasing the stability and growth of the national economy. The success of such a policy largely depends on reforming foreign trade, increasing the country's export potential, and on the ability of the national economy to improve its competitive position in the world market and win new market segments abroad.

Being the second most remote of all landlocked countries, Kyrgyzstan also saw the importance of trade between the neighboring countries for its development and a reduction in poverty. After independence, Kyrgyzstan faced significant challenges, which, initially, resulted in massive inflation and 
a shortage of necessary goods. Despite its geographical disadvantage of being landlocked, at the end of twentieth century, the government of Kyrgyzstan adopted rudimentary market institutions that increased its trade from 0.4 billion to 3.8 billion US dollars from 2000 to 2016 (UN Comtrade Database, 2017). Moreover, the country is located on the "Silk Road", which connects China to Europe, enabling it to increase its trade almost tenfold within our study period. Kyrgyzstan, being a less developed economy, even by Central Asia standards (World Bank, 2016), can only achieve its goals of reducing poverty and becoming more developed by increasing its overall trade with the rest of the world. Therefore, it is essential to study the main determinants of Kyrgyzstan's bilateral trade. In this way, we can help policy makers formulate policies to expand Kyrgyzstan's trade.

This study employs the gravity model, using panel data, to achieve this goal, as this model has been proven to be a suitable practical instrument for investigating the economic factors that determine the trade of a country. We also use this model to estimate the ratio of actual and predicted trade to find unrealized trade potential for Kyrgyzstan and its partners.

Tinbergen (1966) was the first to use gravity model, proposing that the size of bilateral trade flows between any two countries can be approximated by employing the gravity equation. Pöyhönen (1963) later applied the gravity model to explain commercial trade between two partner countries using the gravity equation, in which the product of the GDPs of the two countries were positively correlated, while geographical distance was negatively correlated. Linnemann (1967) included more variables to the gravity model, expanding its theoretical aspect. The theoretical development of the gravity model was continued primarily by the scientific work of (Anderson, 1979; Bergstrand, 1985; Deardorff, 1998; Helpman \& Krugman, 1985). Since 2000, research in this area has been predominantly empirical, adding various factors to the model that demonstrate geographical, cultural, and economic relationships between trading partners. Rahman and Dutta (2012) used the gravity model to analyze total trade (exports and imports) and the overall bilateral trade situation for Bangladesh using the panel data from 1972 to 1999 . The study addressed factors including the exchange rate and each partner country's import demands, and found that openness positively affected the country's exports, while inflation rates, the percapita income differential, transportation cost, and openness were all determinants of the country's imports.

Kurmanalieva (2008) analyzed the main factors behind the changes in Kyrgyzstan's trade pattern. They showed that Kyrgyzstan's trade does not follow the Hecksher-Ohlin or intra-industry models, but that an open and liberal trade policy positively affects the trade volume, since the quality of the infrastructure and transportation costs determine the trade volume of landlocked countries. Sohn (2005) used the gravity model to analyze the trade structure of an AsianPacific trade network to explain South Korea's bilateral trade pattern with 30 major trading countries. Their result showed that South Korea's trade pattern follows Heckscher-Ohlin model. The study also suggested that free-trade agreements with the neighboring countries like China and Japan would promote trade for this country. Thai (2006) also used a gravity model to examine the bilateral trade links between Vietnam and 23 European countries from 1993 to 2004, again using panel data. The result showed that the size of the economy, market, and real exchange rate play an important role in determining the bilateral trade pattern of Vietnam with these European countries. However, distance and history do not play any role in the bilateral trade pattern.

Paas (2000) claimed that the gravity model is especially useful in explaining the transition process because of both is ability to works with small amounts of data and the validity of its theoretical background. They showed that a transitional country such as Estonia should aim for its trade to include the world market, rather than just its neighbors. Khan, UI Haq, and Khan (2013) investigated Pakistan's bilateral trade with its major trading partners. For the time period 19902010 employed the gravity model to successfully explain Pakistan's bilateral trade showing a positive relationship for the product of GDP and GDP per capita, and negative relationship for distance, and a dummy variable for cultural similarities. Employing the ratio of actual and predicted trade, they revealed countries with higher untapped trade potential with Pakistan. Elshehawy, Shen, and Ahmed (2014) studied the factors affecting Egypt's bilateral export flows. They used the gravity model technique for 42 trading partners within a 14-year period. Their results showed that GDP, the importer's population, regional trade agreements (RTAs), and common borders had a positive effect, while distance had an insignificant effect on Egypt's exports.

\section{Kyrgyzstan's Trade Details}

Foreign trade is of particular interest since this activity is the largest and most economically significant part for Kyrgyzstan's foreign economic activity and is also an indicator of the economic situation of the country. As shown in Figure 1, Kyrgyzstan's total exports were US\$0.5bln in 2000 , while imports were US $\$ 0.55 \mathrm{bln}$, leading to a negative trade balance. Except for 2001, when Kyrgyzstan had a slight trade surplus, Kyrgyzstan has maintained a negative trade balance up to the present. Both exports and imports increased throughout our study period, except for 2009 
(when Kyrgyzstan was affected by the 2008 world financial crisis) and 2013 (when it could be explained by the export decrease in gold, dairy products, and sewing products and the import increase in oil products, coal, and wheat). The highest trade deficit recorded was US $\$ 4.21 \mathrm{bln}$ in 2013. In subsequent years, the decrease can be explained by the political and economic instability in neighboring Russia, as Russia was the most important trading partner. However, despite the increasing trade deficit during our study period, we can see an almost five-times increase in a total trade.

Recently, the geographical reach of Kyrgyz trade has expanding considerably. While Kyrgyzstan traded with 137 countries in 2000, it now trades with more than 150 countries (National Statistical Committee of the Kyrgyz Republic, 2016). In our research period, the main trading partners of Kyrgyzstan included Russia, China, Switzerland, Kazakhstan, the US, Uzbekistan, Turkey, and the United Arab Emirates (UN Comtrade Database, 2017). From the continental perspective, Kyrgyzstan's main partners are European and Asian countries.

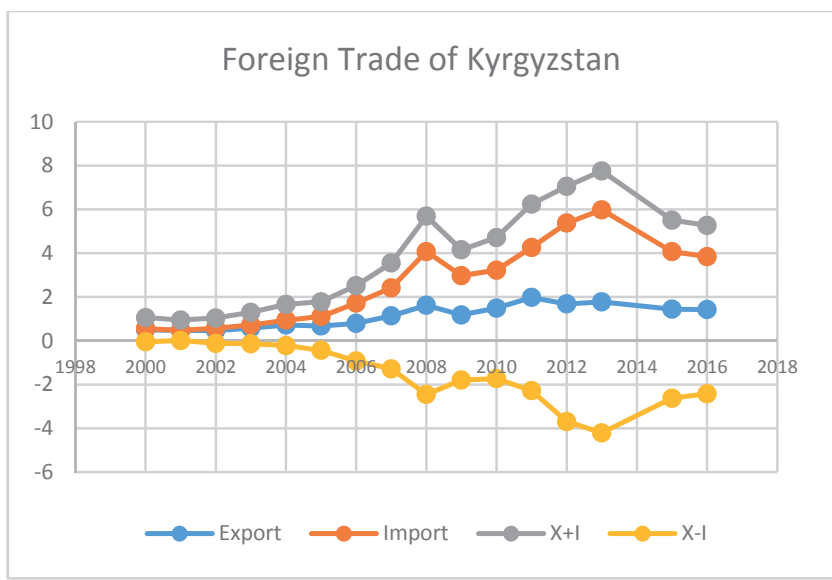

Source: The United Nations Commodity Trade Statistics Database and author's calculations.

Figure 1: Kyrgyzstan foreign trade: 2000-2016 (in US\$ billion).

\section{Research Methodology}

This research attempts to explain Kyrgyzstan's bilateral trade through the gravity model for the years 2000 2016. The research covers 35 countries over 17 years with one dependent and ten independent variables. The data for GDP comes from the World Development Indicators database of the World Bank. Trade data comes from UN Comtrade database and the National Statistical Committee of the Kyrgyz Republic. Annual trade data is calculated at constant 2005 US dollars. Data for distance and cultural similarities comes from CEPII database.
Several models of international trade exist. The gravity model can be categorized as an empirical model analyzing the determinants of interaction. The basic idea behind the approach of the gravitational trade model is that the volume of exports of one country to another is directly proportional to the economic size of these countries because it is their size that determines, respectively, the supply and demand for exports, inversely proportional to the distance between these countries, as the costs of trade in goods grows with the distance between partners. The term "gravity model" is related to the fact that this idea has some similarity with the concept of Newtonian gravity: bodies are attracted with a force proportional to their mass and inversely proportional to the square of the distance between them:

$$
F_{i}=F_{j}=\frac{G * m_{i} * m_{j}}{R^{2}}
$$

where $F_{i}$ and $F_{j}$ are the force between masses, $G$ is the gravitational constant, $m_{i}$ and $m_{j}$ are the masses of the bodies, and $R$ is the distance between the two masses.

By the theory of gravity models and their descriptions, the GDP of the exporting country reflects production opportunities, while the GDP of the importing country is the capacity of its market. In general, these two variables are directly proportional to the volume of trade. The distance between trading partners is inversely proportional. In applying the gravity model for bilateral trade, we analyze the economic mass of the two economies, the distance between them, and other potential factors, such as dummy variables. The basic form of gravity model is given below:

$$
T R_{(i j)}=\alpha_{h} Y_{i}^{\beta} Y_{j}^{\gamma} P_{i}^{\delta} P_{j}^{\varepsilon} D_{i j}^{\theta} U_{i j}
$$

where $T R_{(j)}$ is the trade between partner countries, $\alpha_{h}$ is a constant, $\beta, \gamma, \delta, \varepsilon$, and $\theta$ are coefficients, weighted geometric averages, $Y_{i}^{\beta} Y_{j}^{\gamma}$ represent the GDP of countries $i$ and $j, P_{i}^{\delta} P_{j}^{\varepsilon}$ represent the population of countries $i$ and $j ; D_{i j}^{\theta}$ is the distance between the countries, and $U_{i j}$ is the error term. Other variables are often included to explain a country's trade better.

We convert previous equation to a linear form to make regression analysis possible as follows:

$$
\begin{gathered}
\ln \left(T R_{(i j)}\right)=\alpha+\beta_{1} \ln \left(Y_{i}\right)+\beta_{2} \ln \left(Y_{j}\right)+\beta_{3} \ln \left(P_{i}\right)+\beta_{4} \ln \left(P_{j}\right) \\
+\beta_{5} \ln \left(D_{i j}\right)+U_{i j} .
\end{gathered}
$$

To allow for the possible effects of cultural similarities, we expand and modify the model by adding new independent variables to the original gravity model and establish a model that is suitable for explaining Kyrgyzstan's trade. We take natural logarithms on both sides of the gravity model, 
excluding dummy variables, to overcome the heteroscedasticity problem of the gravity model. The final form of our model expressed as follows:

$$
\begin{aligned}
\ln \left(T R_{(i j)}\right)=\alpha+\beta_{1} & \ln \left(G D P_{i}\right)+\beta_{2} \ln \left(G D P_{j}\right)+\beta_{3} \ln \left(P_{j}\right) \\
& +\beta_{4} \ln \left(D_{i j}\right)+\beta_{5} \text { contig }_{i j}+\beta_{6} \text { langoff }_{i j} \\
& +\beta_{7} \text { langeth }_{i j}+\beta_{8} \text { col }_{i j}+\beta_{9} \text { comcol }_{i j} \\
& +\beta_{10} E E_{i j}+U_{i j}
\end{aligned}
$$

where:

- $i$ is Kyrgyzstan, $j$ is the trading partner;

- $T R_{(i j)}$ is the bilateral trade between Kyrgyzstan and the trading partner;

- $\ln \left(G D P_{i}\right)$ is the Kyrgyzstan gross domestic product (in log) (constant 2005 US\$);

- $\ln \left(G D P_{j}\right)$ is the trading partner's gross domestic product (in log) (constant 2005 US\$);

- $\ln \left(P_{j}\right)$ is the trading partner's population (in log);

- $\ln \left(D_{i j}\right)$ is the distance between Bishkek and trading partner's capital (in log);

- contig $_{i j}$ is the (dummy) for whether the two countries have a common border;

- langoff $f_{i j}$ is the (dummy) for whether the two countries have an official common language;

- langeth $_{i j}$ is the (dummy) for whether the two countries have a common language spoken by at least $9 \%$ of the population in both countries;

- $\mathrm{col}_{i j}$ is the (dummy) for whether the two countries had a colonial link;

- comcol $_{i j}$ is the (dummy) for whether the two countries had a common colonizer after 1945; and

- $E E U_{i j}$ is the (dummy) for whether the two countries are members of the Eurasian Economic Union.

According to economic theory, the expected signs of variables $\beta_{1}, \beta_{2}$ are positive because a high level of income in trading partners shows a high level of production, while $\beta_{3}$ can be either positive or negative, depending on the opportunity to trade in a large variety of goods. $\beta_{4}$ is expected to have a negative sign as it increases trade costs. Other dummy variables, $\beta_{5}, \beta_{6}, \beta_{7}, \beta_{8}, \beta_{9}, \beta_{10}$, are expected to have a positive sign as cultural similarities and economic unions eliminate obstacles to trade and make an increase in trade more likely.

\section{Results}

Table 1 shows descriptive statistics of variables. Table 2 shows that GDP, population, distance, and the other six dummy variables are significant. The signs of the coefficients are the expected signs, with the clear exception of common language and membership of the Eurasian Economic Union. They were both supposed to have a positive sign in the gravity model. R-squared for the equation is 0.6389 , which indicates that the total performance of the model is quite strong. The coefficient of determination $\left(R^{2}\right)$ for this model suggests that $63 \%$ of the variations in the dependent variable are explained by independent variables. The value of the adjusted R-square is 0.6327 . The significance of this model reveals that the bilateral trade of Kyrgyzstan is well explained by gravity model.

Table 1: Descriptive statistics of variables.

\begin{tabular}{|c|c|c|c|c|c|}
\hline Variable & Obs & Mean & $\begin{array}{c}\text { Std. } \\
\text { Dev. }\end{array}$ & Min & Max \\
\hline In_trade & 595 & 16.817 & 1.820 & 11.225 & 21.484 \\
\hline In_gdp_part & 595 & 26.243 & 2.031 & 21.667 & 30.456 \\
\hline In_gdp_kyrg & 595 & 22.223 & 0.211 & 21.888 & 22.566 \\
\hline Inpoppart & 595 & 16.884 & 1.595 & 14.089 & 21.044 \\
\hline In_distance & 595 & 8.151 & 0.679 & 6.174 & 9.352 \\
\hline contig & 595 & 0.114 & 0.318 & 0 & 1 \\
\hline comlang_off & 595 & 0.057 & 0.232 & 0 & 1 \\
\hline comlang_ethno & 595 & 0.085 & 0.280 & 0 & 1 \\
\hline colony & 595 & 0.028 & 0.166 & 0 & 1 \\
\hline comcol & 595 & 0.342 & 0.475 & 0 & 1 \\
\hline EEU & 595 & 0.114 & 0.318 & 0 & 1 \\
\hline
\end{tabular}

Table 2: Variables and their significance.

\begin{tabular}{|c|c|}
\hline Variable & In_trade \\
\hline In_gdp_kyrg & $2.065(9.30)^{\star *}$ \\
\hline In_gdp_partner & $0.825(11.25)^{\star *}$ \\
\hline In_distance & $-0.644(-4.91)^{\star *}$ \\
\hline In_poppart & $-0.259(-4.10)^{* *}$ \\
\hline contig & $2.279(9.25)^{\star *}$ \\
\hline comlang_off & $-1.200(-2.63)^{\star *}$ \\
\hline colony & $3.145(6.79)^{\star *}$ \\
\hline comlang_ethno & $1.762(3.89)^{\star *}$ \\
\hline comcol & $0.883(4.68)^{\star *}$ \\
\hline EEU & $-0.359(1.02)$ \\
\hline cons & $-41.806(8.44)^{* *}$ \\
\hline$R^{2}$ & 0.64 \\
\hline$N$ & 595 \\
\hline
\end{tabular}

Note: ${ }^{*} p<0.05 ;{ }^{* *} p<0.01$

In our analysis of the results, we consider that all other variables remain constant. In case of the two countries' GDP, $\beta_{1}, \beta_{2}$, a positive sign is as expected, and the estimated coefficient is significantly different from zero. The estimated coefficient of Kyrgyzstan's GDP is 2.07, which suggests that, if Kyrgyzstan's GDP goes up by $1 \%$, 
Kyrgyzstan's bilateral trade will result in a roughly 2-point increase. Similarly, the estimated coefficient of trading partners' GDP is 0.81 , which suggests that, if the trading partners' GDP goes up 1\%, Kyrgyzstan's bilateral trade will result in a 0.81 -point increase. The population variable, $\beta_{3}$, has a negative sign in our analysis.

As expected, the distance, $\beta_{4}$, is statistically significant, with a negative sign, proving that geographical distance is a significant resistance factor for Kyrgyzstan's bilateral trade. Our result of -0.644 is consistent with many previous studies.

According to the model, our dummy variables are all statistically significant, except for membership of the Eurasian Economic Union. The union initially intended to lower tariff barriers within member states (Russia, Belarus, Kazakhstan, Armenia, and Kyrgyzstan) but is not significant to Kyrgyzstan's bilateral trade. It may be explained by the fact that the union is not working at its full potential, having had many political problems and disputes in the initial stages.

According to theoretical expectations, countries that share the same language should have more trade with each other, but our model is not consistent with that theory. In our study, the estimated coefficient of trade between countries who have Russian as an official language has a negative sign.

The gravity model estimation also gives us an opportunity to find the untapped trade potential of Kyrgyzstan with its main trading partners. The coefficients obtained from the gravity model are used to predict trade potential for Kyrgyzstan. We compare actual and predicted trade volume for the year 2016. The ratio of actual and predicted trade is employed for this. The difference will indicate unrealized trade potential between trading partners. If the ATR/PTR (\%) is more than $100 \%$, then Kyrgyzstan exceeded its trade potential with that particular country. If it is less than $100 \%$, there is still unrealized trade potential. The results are shown in Table 3. We can see that Kyrgyzstan has a good trade potential with most countries.

If we analyze the trade between neighboring countries and Russia, we see comparatively lower ratios with China, Kazakhstan, Uzbekistan, Russia, and Tajikistan (51\%, 31\%, $17 \%, 23 \%$, and $17 \%$, respectively). From these results, we can conclude there are still significant barriers to trade that result in a considerable level of untapped potential for trade. China, with a ratio of $51 \%$, implies that $49 \%$ of its total trade potential with Kyrgyzstan is unrealized. Similarly, in the cases of Kazakhstan, Russia, Uzbekistan, and Tajikistan $69 \%, 83 \%, 77 \%$, and $83 \%$, respectively, of total trade potential is found to be unrealized. As a rule, lower ratios indicate that countries are better partners for free-trade agreements as the elimination of trade barriers will lead to realizing the untapped trade potential, resulting in an increase in Kyrgyzstan's trade.
Table 3: Kyrgyzstan's trade potential.

\begin{tabular}{|c|c|c|c|}
\hline Country & $\begin{array}{l}\text { Actual } \\
\text { trade }\end{array}$ & $\begin{array}{l}\text { Predicted } \\
\text { trade }\end{array}$ & ATR/PTR (\%) \\
\hline Switzerland & 659.70 & 67.94 & 970.9 \\
\hline Turkey & 280.75 & 111.25 & 252.4 \\
\hline Ukraine & 42.95 & 51.23 & 83.8 \\
\hline Bulgaria & 8.39 & 15.82 & 53.0 \\
\hline China & 1544.66 & 3027.89 & 51.0 \\
\hline United Arab Emirates & 40.19 & 91.94 & 43.7 \\
\hline USA & 154.04 & 355.38 & 43.3 \\
\hline Lithuania & 15.68 & 43.07 & 36.4 \\
\hline Kazakhstan & 786.70 & 2506.24 & 31.4 \\
\hline Georgia & 6.37 & 21.44 & 29.7 \\
\hline Belgium & 20.51 & 74.55 & 27.5 \\
\hline Germany & 68.79 & 251.15 & 27.4 \\
\hline Latvia & 8.56 & 32.16 & 26.6 \\
\hline Poland & 16.92 & 69.89 & 24.2 \\
\hline Russian Federation & 945.03 & 4066.28 & 23.2 \\
\hline United Kingdom & 41.24 & 181.61 & 22.7 \\
\hline Belarus & 36.06 & 163.22 & 22.1 \\
\hline Rep. of Korea & 26.45 & 120.91 & 21.9 \\
\hline Romania & 7.83 & 35.84 & 21.8 \\
\hline Iran & 14.74 & 75.19 & 19.6 \\
\hline Rep. of Moldova & 1.69 & 9.30 & 18.2 \\
\hline Uzbekistan & 194.84 & 1099.71 & 17.7 \\
\hline Czech Rep. & 7.46 & 42.57 & 17.5 \\
\hline Turkmenistan & 10.06 & 58.60 & 17.2 \\
\hline Tajikistan & 28.27 & 165.18 & 17.1 \\
\hline Italy & 25.83 & 157.33 & 16.4 \\
\hline India & 24.99 & 168.96 & 14.8 \\
\hline Azerbaijan & 7.26 & 55.54 & 13.1 \\
\hline France & 23.21 & 186.35 & 12.5 \\
\hline Netherlands & 12.69 & 106.41 & 11.9 \\
\hline Austria & 8.09 & 74.15 & 10.9 \\
\hline Canada & 10.97 & 104.55 & 10.5 \\
\hline Finland & 2.65 & 60.95 & 4.3 \\
\hline Estonia & 0.96 & 30.20 & 3.2 \\
\hline Australia & 1.37 & 81.25 & 1.7 \\
\hline
\end{tabular}

Source: The United Nations Commodity Trade Statistics Database and author's calculations.

\section{Conclusion and Implication}

Kyrgyzstan is a small, landlocked country with mountainous areas. It has achieved economic growth by expanding trade flows. Thus, it is of interest to examine the extent to which the gravity model is applicable in explaining Kyrgyzstan's bilateral trade. Our empirical results show that the gravity-model approach, with high values of R-square, is effective in explaining Kyrgyzstan's bilateral trade. All the variables used in our model were found to be significant, except for membership of the Eurasian Economic Union. The distance between Bishkek and trading partner's capitals 
has a negative relationship. Dummy variables showed a significant positive relationship towards trade volume. Untapped trade potential indicated in case of Kyrgyzstan's trade with any country, excluding Switzerland and Turkey, is less than that predicted by the gravity model. Comparatively lower ratios were found for neighboring China, Kazakhstan, Uzbekistan, Russia, and Tajikistan for the year 2016.

The policy implications related to the findings of unrealized trade potential range from the need to promote trade with particular countries, including bilateral integration, to the need to anticipate relevant distributional changes due to the effect of the expansion in bilateral trade flows in the near future. From the findings above we make the following policy recommendations. Firstly, Kyrgyzstan should take measures to increase its trade with large economies as there is a positive significant relationship between GDP and trade volume. Secondly, economic objectives should be the priority and not suffer because of political disputes. Thirdly, countries like China, Kazakhstan, Uzbekistan, Russia, and Tajikistan should be considered for trade agreements as they still have largely unrealized trade potential and involve low transportation costs.

\section{References}

Anderson, J. E. (1979). A theoretical foundation for the gravity equation. American Economic Review, 69(1), 106116. https://doi.org/10.1126/science.151.3712.867-a

Bergstrand, J. H. (1985). The Gravity Equation in International Trade: Some Microeconomic Foundations and Empirical Evidence. The Review of Economics and Statistics, 67(3), 474-481. https://doi.org/10.2307/1925976

Deardorff, A. V. (1998). Determinants of Bilateral Trade: Does Gravity Work in a Neoclassical World?. In Jeffrey A. Frankel (Ed.), The Regionalization of the World Economy (p.7-32), University of Chicago Press. Retrieved from http://www.nber.org/ chapters/c7818

Elshehawy, M. A., Shen, H., \& Ahmed, R. A. (2014). The factors affecting Egypt's exports: Evidence from the gravity model analysis. Open Journal of Social Sciences, 2(11), 138-148.

Helpman, E., \& Krugman, P. R. (1985). Market structure and foreign trade: Increasing returns, imperfect competition, and the international economy. Cambridge, MA: MIT press.

Khan, S., Ul Haq, I., \& Khan, D. (2013). An Empirical Analysis of Pakistan's Bilateral Trade: A Gravity Model
Approach. The Romanian Economic Journal, 48, 103-120. Retrieved from http://citeseerx.ist.psu.edu/viewdoc/ download?doi=10.1.1.906.7050\&rep=rep1\&type=pdf

Kurmanalieva, E. (2008). Empirical analysis of Kyrgyz trade patterns. Eurasian Journal of Business and Economics, 1(1), 83-97.

Linnemann, H. (1967). An Econometric Study of International Trade Flows. The Economic Journal, 77(306), 366-368.

Paas, T. (2000). Gravity approach for modeling trade flows between Estonia and the main trading partners. University of Tartu, Faculty of Economics and Business Administration Working Paper (No. 4). Tiigi, Tartu: Tartu University Press. Available at: https://www.mtk.ut.ee/sites /default/files/mtk/toimetised/febawb4.pdf

Pöyhönen, P. (1963). A tentative model for the volume of trade between countries. Weltwirtschaftliches Archiv, 90, 93-100.

Rahman, M.M., \& Dutta, D. (2012). The Gravity Model Analysis of Bangladesh's Trade: A Panel Data Approach. Journal of Asia-Pacific Business, 13(3), 263-286,

DOI: 10.1080/10599231.2012.687616

Sohn, C.-H. (2005). Does the gravity model explain South Korea's trade flows? The Japanese Economic Review, 56(4), 417-430.

Thai, T. Do. (2006). A gravity model for trade between Vietnam and twenty-three European countries. Available at: http://www.diva-portal.org/smash/get/diva2:518029/ FULLTEXT01.pdf

Tinbergen, J. (1966). Shaping the World Economy; Suggestions for an International Economic Policy. The Economic Journal, 76(301), 92-95.

Mayer, T., \& Zignago, S. (2011). Notes on CEPII's distances measures. The GeoDist database. Retrieved December 25, 2017, from http://www.cepii.fr/cepii/en/bdd_modele /bdd.asp

National Statistical Committee of the Kyrgyz Republic (2016). 2016 Annual Reports. Bishkek City, Kyrgyz Republic. Retrieved December 31, 2017, from: http://stat.kg/en/

UNSD (2017). UN Comtrade International Trade Statistics Database. Retrieved December 20, 2017, from: https://comtrade.un.org/.

World Bank. (2016). World Development Indicators 2016. Retrieved December 23, 2017, from: http://databank.worldbank.org/data/reports.aspx?source= world-development-indicators 